\title{
Hubungan Pemberian ASI terhadap Kejadian Stunting Pada Balita 24 Bulan di Wilayah Kerja Puskesmas Emparu Kabupaten Sintang
}

\section{The Relationship of Breastfeeding to the Incidence of Stunting in Toddlers 24 Months in the Work Area of the Emparu Community Health Center Sintang District}

\author{
Kiki Lusrizanuri ${ }^{*}$ \\ ${ }^{1}$ STIKes Kapuas Raya Sintang, Kalimantan Barat, Indonesia \\ *Korespondensi penulis: Kikizanuri@yahoo.co.id
}

Penyerahan: 15-09-2020, Perbaikan: 11-12-2020, Diterima: 13-12-2020

\begin{abstract}
Stunting is a disorder of growth and physical development in children characterized by height and weight reduction in the growth rate of development in children. This study aims to determine the relationship between breastfeeding and the incidence of stunting in under five 24 months old in the working area of the Emparu Health Center. This research is a quantitative study with a cross sectional approach. The data collection technique used a structured questionnaire. Sampling using a total sampling of 60 respondents. Univariate and bivariate data analysis used the Chi Square test. The results of univariate analysis showed that respondents who gave ASI were $88.3 \%$ and did not give ASI as much as $11.7 \%$. The results of the bivariate analysis showed that there was a significant relationship between the variable of breastfeeding and the incidence of stunting at the age of 24 months with a value of Pvalue $=0.013$. It was found that the incidence of stunting in breastfeeding was 35\%, it is hoped that parents who have toddlers must attend Posyandu activities every month to determine the development and growth of children under five.
\end{abstract}

Keywords: Giving Breast Milk and Stunting.

\begin{abstract}
ABSTRAK
Stunting merupakan gangguan pertumbuhan dan perkembangan fisik pada anak yang ditandai dengan tinggi badan dan berat badan penurunan kecepatan pertumbuhan dalam perkembangan pada anak. Penelitian ini bertujuan untuk mengetahui hubungan pemberian asi terhadap kejadian stunting pada balita 24 bulan di Desa Wilayah Kerja Puskesmas Emparu. Penelitian ini adalah penelitian kuantitatif dengan pendekatan cross sectional. Teknik pengumpulan data menggunakan kuesioner terstruktur. Pengambilan sampel menggunakan total sampling sebanyak 60 responden. Analisis data secara univariat dan bivariat menggunakan uji Chi Square. Hasil analisis univariat didapatkan responden yang memberikan ASI sebanyak $88,3 \%$ dan tidak memberikan ASI sebanyak $11,7 \%$. Hasil analisis bivariat didapatkan bahwa ada hubungan yang signifikan antara variabel pemberian ASI dengan kejadian stunting pada usia 24 bulan dengan nilai Pvalue $=0,013$. Didapatkan kejadian stunting pada pemberian ASI sebesar $35 \%$, diharapkan kepada orangtua yang mempunyai balita harus mengikuti kegiatan posyandu setiap bulan guna mengetahui perkembangan dan pertumbuhan balita.
\end{abstract}

Kata kunci: Pemberian ASI dan Stunting.

Jurnal Dunia Kesmas, Vol. 9 No. 4, Oktober 2020, hal. 529-536 


\section{PENDAHULUAN}

Stunting merupakan gangguan pertumbuhan fisik yang sudah lewat, berupa penurunan kecepatan pertumbuhan dalam perkembangan manusia yang merupakan dampak utama dari gizi kurang. Stunting meningkatkan resiko kematian anak, mempengaruhi perkembangan motorik, meningkatkan resiko penyakit menular, dan mengurangi produktivitas anak ketika dewasa. Hal ini juga bisa disebabkan karena defisiensi dari berbagai zat gizi, misalnya mikronutrien, protein atau energi. Stunting pada anak merupakan salah satu faktor penghambat bagi pembangunan manusia.

Angka kejadian stunting di Indonesia pada tahun 2018 sebesar 30,8\%. Di Provinsi Kalimantan Barat angka kejadian stunting pada tahun 2018 sebesar 34\%. Sedangkan angka kejadian stunting di Kabupaten Sintang Tahun 2018 sebesar 33,2\%. Kemudian, angka kejadian stunting di Wilayah Kerja Puskesmas Emparu pada tahun 2018 sebesar 3,37\% dengan 24 balita yang mengalami stunting.

Masalah gizi berkaitan erat dengan gizi pada balita. Pemenuhan gizi pada balita salah satunya melalui pemberian ASI. Selain pemberian ASI pada balita maka diberikan juga makanan pendamping ASI (MP-ASI). Pola pemberian makanan terutama pada 2 tahun pertama kehidupan, yaitu ASI dan makanan pendamping (MP-ASI) yang dapat mempengaruhi status gizi balita. Menurut Proverawati tahun 2010, menyatakan bahwa ASI mengandung growth faktor yang melindungi bayi terhadap infeksi dan juga merangsang pertumbuhan bayi yang normal. Demikian juga, status menyusui juga merupakan faktor risiko terhadap kejadian stunting.
Secara Nasional data pemberian ASI Ekslusif di Indonesia pada tahun 2019 sebesar 58\% dan $42 \%$ tidak memberikan ASI secara Ekslusif. Angka tersebut sudah mencapai target nasional sebesar $39 \%$. Persentase pemberian ASI Ekslusif di Kalimantan Barat sampai dengan tahun 2019 belum mencapai target Provinsi Kalimantan barat yaitu sebesar $77 \%$ dimana $68,4 \%$ diantaranya memberikan ASI secara Ekslusif dan 31,6\% memberikan ASI secara tidak Ekslusif. Perilaku ibu dalam pemberian ASI Eksklusif memiliki hubungan yang bermakna dengan indeks $P B / U$, dimana 48 dari 51 anak stunting tidak mendapatkan ASI Eksklusif. Anak balita yang diberikan ASI sesuai dengan kebutuhannya pada umumnya dapat mengurangi resiko terjadinya stunting.

Wilayah kerja Puskesmas Emparu Kecamatan Kelam Permai Kabupaten Sintang, Provinsi Kalimantan Barat merupakan salah satu dengan angka kejadian stunting urutan ketiga di Kabupaten Sintang. Penelitian ini bertujuan untuk mengetahui Hubungan Pemberian ASI Terhadap Kejadian Stunting Pada Balita 24 Bulan di Wilayah Kerja Puskesmas Emparu Kabupaten Sintang.

\section{METODE}

Penelitian ini merupakan penelitian kuantitatif dengan pendekatan cross sectional. Cross sectional yaitu suatu rancangan penelitian dimana variabel independen dan variabel dependen diukur pada waktu penelitian berlangsung yang dapat menjelaskan suatu hubungan. Sampel dalam penelitian ini adalah orangtua yang memiliki balita usia 24 bulan berjumlah 60 responden, data ini diambil di Puskesmas Emparu. Data yang dikumpulkan meliputi riwayat pemberian ASI dan untuk mengetahui 
stunting menggunakan antropometri pada balita. Pengambilan sampel menggunakan total sampling. Variabel dalam penelitian ini pemberian ASI.

Indeks TB/U merupakan indeks antropometri yang menggambarkan keadaan status gizi balita yang merupakan padanan istilah stunting (pendek). Stunting pada balita ditentukan berdasarkan keadaan status gizi seseorang berdasarkan zscore tinggi badan (TB) terhadap umur (U) dimana terletak pada <-2 SD berdasarkan hasil pengukuran. Analisis data yang digunakan adalah analisis univariat dan analisis bivariat dengan menggunakan uji Chi Square. Tingkat kemaknaan 95\% $(a=0,05)$, yang digunakan untuk mengetahui adanya hubungan antara Pemberian ASI dengan Kejadian Stunting pada Balita 24 bulan.merokok dan kegemukan. Kuesioner penelitian telah dinyatakan valid dan reliable setelah sebelumnya diuji validitas dan reliabilitas kuesioner. Adapun isi dari kuesioner menanyakan variabel penelitian dan pertanyaan mengenai karakteristik responden. Variabel penelitian yang dimaksud antara lain hobi makan makanan cepat saji, hobi minum minuman bersoda, memiliki orang tua yang berstatus gemuk, berolahraga, suka makan gorengan, pecandu game, bukan perokok dan responden tidak gemuk. Variabel kegemukan diukur dengan menghitung Indeks Masa Tubuh responden. Analisis data dalam penelitian ini menggunakan Chi Square dengan bantuan aplikasi statistik komputer yang bertujuan untuk mengukur risiko variabel bebas terhadap variabel terikat.

\section{HASIL}

Tabel 1. Distribusi Frekuensi Kejadian Stunting Pada Balita Di Wilayah Kerja Puskesmas Emparu Tahun 2020

\begin{tabular}{cccc}
\hline No & Kejadian Stunting & Frekuensi & Persentase(\%) \\
\hline 1 & Tidak Stunting & 39 & 65 \\
2 & Stunting & 21 & 35 \\
& Total & 60 & 100 \\
\hline
\end{tabular}

Tabel 1 menunjukkan bahwa distribusi frekuensi kejadian stunting pada pada balita 24 bulan di wilayah kerja Puskesmas Emparu Kabupaten
Sintang Tahun 2020, didapatkan responden yang tidak stunting sebanyak $65 \%$ sedangkan responden yang stunting sebanyak $35 \%$.

Tabel 2. Distribusi Frekuensi Pemberian ASI Pada Balita di Desa Wilayah Kerja Puskesmas Emparu Tahun 2020

\begin{tabular}{clcc}
\hline No & Pemberian ASI & Frekuensi & Persentase(\%) \\
\hline 1 & Memberikan & 53 & 88,3 \\
2 & Tidak Memberikan & 7 & 11,7 \\
& Total & 60 & 100 \\
\hline
\end{tabular}

Tabel 2 menunjukkan bahwa distribusi frekuensi pemberian ASI pada balita di Wilayah Kerja Puskesmas Emparu Kabupaten Sintang Tahun 2020, didapatkan responden yang memberikan ASI sebanyak $88,3 \%$ sedangkan responden yang tidak memberikan ASI sebanyak $11,7 \%$. 


Tabel 3. Distribusi Frekuensi Umur Pada Balita di Desa Wilayah Kerja
\begin{tabular}{cccc}
\multicolumn{4}{c}{ Puskesmas Emparu Tahun $\mathbf{2 0 2 0}$} \\
\hline No & Umur & Frekuensi & Persentase(\%) \\
\hline 1 & Umur $<12$ Bulan & 25 & 41,7 \\
2 & Umur 12-24 Bulan & 35 & 58,3 \\
& Total & 60 & 100 \\
\hline \multicolumn{4}{c}{}
\end{tabular}

Tabel 3 menunjukkan bahwa distribusi frekuensi umur pada balita di Wilayah Kerja Puskesmas Emparu Kabupaten Sintang Tahun 2020, didapatkan umur umur 12-24 bulan sebanyak $58,3 \%$ sedangkan umur < 12 bulan sebanyak $41,7 \%$.

Tabel 4. Distribusi Frekuensi Jenis Kelamin Pada Balita di Desa Wilayah Kerja Puskesmas Emparu Tahun 2020

\begin{tabular}{cccc}
\hline No & Jenis Kelamin & Frekuensi & Persentase(\%) \\
\hline 1 & Laki-laki & 34 & 56,7 \\
2 & Perempuan & 26 & 43,3 \\
& Total & 60 & 100 \\
\hline
\end{tabular}

Tabel 4 menunjukkan bahwa distribusi frekuensi jenis kelamin pada balita di Wilayah Kerja Puskesmas Emparu Kabupaten Sintang Tahun 2020, didapatkan balita yang berjenis kelamin laki-laki sebanyak $56,7 \%$ sedangkan balita yang berjenis kelami perempuan sebanyak $43,3 \%$.

Tabel 3. Hubungan Stunting dengan Pemberian ASI, Umur, dan Jenis Kelamin di Wilayah Kerja Puskesmas Emparu Tahun 2020

\begin{tabular}{|c|c|c|c|c|c|c|c|c|}
\hline \multirow{3}{*}{ No } & \multirow{3}{*}{ Variabel } & \multicolumn{4}{|c|}{ Kejadian Stunting } & \multirow{2}{*}{\multicolumn{2}{|c|}{ Total }} & \multirow{3}{*}{$\mathbf{P}_{\text {value }}$} \\
\hline & & \multicolumn{2}{|c|}{ Stunting } & \multicolumn{2}{|c|}{$\overline{\text { Tidak Stunting }}$} & & & \\
\hline & & $\mathbf{n}$ & $\%$ & $\mathbf{n}$ & $\%$ & $\mathbf{n}$ & $\%$ & \\
\hline \multicolumn{9}{|c|}{ Pemberian ASI } \\
\hline 1 & $\begin{array}{l}\text { Tidak Memberikan } \\
\text { ASI }\end{array}$ & 34 & 75,6 & 6 & 40 & 40 & 66,7 & 0,013 \\
\hline 2 & Memberikan ASI & 11 & 24,4 & 9 & 60 & 20 & 33,3 & \\
\hline \multicolumn{9}{|c|}{ Umur } \\
\hline 1 & Umur $<12$ Bulan & 25 & 53,2 & 5 & 38 & 30 & 50 & 0,008 \\
\hline 2 & Umur 12-24 Bulan & 22 & 46,8 & 8 & 62 & 30 & 50 & \\
\hline \multicolumn{9}{|c|}{ Jenis Kelamin } \\
\hline 1 & Laki-laki & 36 & 75 & 4 & 33 & 40 & 66,7 & 0,015 \\
\hline 2 & Perempuan & 12 & 25 & 8 & 67 & 20 & 33,3 & \\
\hline
\end{tabular}

Tabel 3 menunjukan bahwa responden dengan stunting yang tidak diberikan ASI sebanyak 75,6\% dan responden yang tidak stunting yang tidak diberikan ASI sebanyak $40 \%$. Sedangkan responden dengan stunting yang diberikan ASI sebanyak $24,4 \%$ dan responden yang tidak diberikan ASI tapi tidak stunting sebanyak 60\%. Hasil uji statistik diperoleh $P_{\text {value }}=0,013<0,05$ berarti ada hubungan pemberian ASI terhadap kejadian stunting pada balita 24 bulan di wilayah kerja Puskesmas Emparu Kabupaten Sintang Tahun 2020. Responden 
dengan stunting yang berumur $<12$ Bulan sebanyak $53,2 \%$ dan responden yang tidak stunting berumur < 12 bulan sebanyak 38\%. Sedangkan responden dengan stunting yang berumur 12-24 bulan sebanyak $46,8 \%$ dan responden yang tidak stunting berumur $12-24$ bulan sebanyak 62\%. Hasil uji statistik diperoleh $P_{\text {value }}=0,008<0,05$ berarti ada hubungan umur terhadap kejadian stunting pada balita 24 bulan di wilayah kerja Puskesmas Emparu Kabupaten Sintang Tahun 2020. Kemudian responden dengan stunting jenis kelamin laki-laki sebanyak $75 \%$ dan responden tidak stunting jenis kelamin laki-laki sebanyak 33\%. Sedangkan responden dengan stunting jenis kelamin perempuan sebanyak $25 \%$ dan responden tidak stunting jenis kelamin perempuan sebanyak $67 \%$. Hasil uji statistik diperoleh $P_{\text {value }}=$ $0,015<0,05$ berarti ada hubungan jenis kelamin terhadap kejadian stunting pada balita 24 bulan di wilayah kerja Puskesmas Emparu Kabupaten Sintang Tahun 2020.

\section{PEMBAHASAN}

$\begin{array}{ccc}\text { Hasil analisis } & \text { bivariat } \\ \text { menunjukan } & \text { responden } & \text { dengan }\end{array}$ stunting yang tidak diberikan ASI sebanyak $75,6 \%$ dan responden yang tidak stunting yang tidak diberikan ASI sebanyak $40 \%$. Sedangkan responden dengan stunting yang diberikan ASI sebanyak $24,4 \%$ dan responden yang tidak diberikan ASI tapi tidak stunting sebanyak $60 \%$. Hasil uji statistik diperoleh Pvalue = $0,013<0,05$ berarti ada hubungan pemberian ASI terhadap kejadian stunting pada balita 24 bulan di wilayah kerja Puskesmas Emparu Kabupaten Sintang Tahun 2020. Menurut hasil Penelitian Setiawan, E., Machmud, R., \& Masrul, $M$ tahun 2018, yang berjudul faktorfaktor yang berhubungan dengan kejadian stunting pada anak usia 2459 bulan di Wilayah Kerja Puskesmas Andalas Kecamatan Padang Timur Kota Padang.Berdasarkan hasil penelitian menunjukan bahwa ada hubungan yang bermakna antara pemberian ASI dengan kejadian stunting pada anak usia 24-59 bulan dengan nilai Pvalue 0.004 .

Masalah kurang gizi dan stunting merupakan dua masalah yang saling berhubungan. Stunting pada balita merupakan dampak dari defisiensi nutrien selama seribu hari pertama kehidupan. Hal ini menimbulkan gangguan perkembangan fisik anak yang irreversible, sehingga menyebabkan penurunan kemampuan kognitif dan motorik serta penurunan performa kerja. Anak stunting memiliki rerata skor Intelligence Quotient (IQ) sebelas poin lebih rendah dibandingkan rerata skor IQ pada anak normal. Gangguan tumbuh kembang pada anak akibat kekurangan gizi bila tidak mendapatkan intervensi sejak dini akan berlanjut hingga dewasa.

Balita dengan stunting perlu mendapatkan perhatian khusus karena dapat menyebabkan terhambatnya pertumbuhan fisik, perkembangan mental dan status kesehatan pada balita. Studi terkini menunjukkan balita yang mengalami stunting berkaitan dengan prestasi di sekolah yang buruk, tingkat pendidikan yang rendah dan pendapatan yang rendah saat dewasa. Balita yang mengalami stunting memiliki kemungkinan lebih besar tumbuh menjadi individu dewasa yang tidak sehat dan miskin. Stunting pada balita juga berhubungan dengan peningkatan kerentanan balita terhadap penyakit, baik penyakit menular maupun Penyakit Tidak Menular (PTM) serta peningkatan risiko overweight dan obesitas. Keadaan overweight dan 
obesitas jangka panjang dapat meningkatkan risiko penyakit degeneratif. Kasus stunting pada balita dapat dijadikan prediktor rendahnya kualitas sumber daya manusia suatu negara. Keadaan stunting menyebabkan buruknya kemampuan kognitif, rendahnya produktivitas, serta meningkat risiko penyakit mengakibatkan kerugian jangka panjang bagi ekonomi Indonesia.

Asumsi peneliti perkembangan balita yang berada dalam kategori rendah dapat disebabkan oleh tingkat kesejahteraan keluarga yang rendah, dimana sebagian dari orang tua balita di wilayah kerja Puskesmas Emparu bekerja sebagai petani. Hal ini juga dapat didukung oleh lingkungan serta budaya yang mendukung pemberian makanan bagi balita.Adanya stunting pada balita di wilayah kerja Puskesmas Emparu, seharusnya menjadi pelajaran bagi orang tua dalam merawat balita khususnya memberikan ASI, memberikan makanan tambahan agar balita tidak stunting.

$\begin{array}{ccc}\text { Hasil analisis } & \text { bivariat } \\ \text { menunjukan } & \text { responden } & \text { dengan }\end{array}$ stunting yang berumur $<12$ Bulan sebanyak $53,2 \%$ dan responden yang tidak stunting berumur $<12$ bulan sebanyak 38\%. Sedangkan responden dengan stunting yang berumur 12-24 bulan sebanyak $46,8 \%$ dan responden yang tidak stunting berumur 12-24 bulan sebanyak $62 \%$. Hasil uji statistik diperoleh Pvalue $=0,008<0,05$ berarti ada hubungan umur terhadap kejadian stunting pada balita 24 bulan di wilayah kerja Puskesmas Emparu Kabupaten Sintang Tahun 2020.

Anak usia 0-24 bulan mempunyai risiko mengalami anemia defisiensi besi karena meningkatnya kebutuhan zat besi serta makanan yang tidak cukup mengandung zat besi. Disamping itu, anemia defisiensi besi merupakan faktor risiko terjadinya defisiensi seng. Interaksi zat besi dan seng berdampak pada hambatan pertumbuhan tinggi badan sehingga anak terlahir pendek. Defisiensi seng dapat mengakibatkan gagal tumbuh, penurunan nafsu makan, dan penyembuhan luka yang lambat.

Hasil penelitian ini sejalan dengan penelitian yang dilakukan di Kalimantan Barat yang mengambil subjek stunting pada umur 6-36 bulan. Pada penelitian ini juga dijelaskan bahwa kemunculan stunting dimulai dari usia 6 bulan dan muncul utamanya pada usia 2-3 tahun dan memberikan dampak jangka panjang.

Hasil analisis bivariat

menunjukan responden dengan stunting jenis kelamin laki-laki sebanyak $75 \%$ dan responden tidak stunting jenis kelamin laki-laki sebanyak $33 \%$. Sedangkan responden dengan stunting jenis kelamin perempuan sebanyak $25 \%$ dan responden tidak stunting jenis kelamin perempuan sebanyak $67 \%$. Hasil uji statistik diperoleh Pvalue = $0,015<0,05$ berarti ada hubungan jenis kelamin terhadap kejadian stunting pada balita 24 bulan di wilayah kerja Puskesmas Emparu Kabupaten Sintang Tahun 2020.

Hasil penelitian ini didukung oleh studi kohort yang dilakukan Medin (2010) yang menunjukan bayi dengan jenis kelamin laki-laki memiliki risiko dua kali lipat menjadi stunting dibandingkan bayi perempuan. Demikian juga penelitian yang dilakukan oleh Lesiapato (2010) di sub-Sahara Afrika menunjukan bahwa balita laki-laki prasekolah berisiko stunting dibanding rekan perempuannya.

Jenis kelamin menentukan pula besar kecilnya kebutuhan gizi untuk seseorang. Laki-laki lebih banyak 
membutuhkan zat tenaga dan protein dibandingkan perempuan. Laki-laki lebih sanggup mengerjakan pekerjaan berat yang tidak bisa dilakukan perempuan. Selama masa bayi dan balita, balita perempuan cenderung lebih rendah kemungkinannya menjadi stunting daripada balita laki-laki, selain itu bayi perempuan dapat bertahan hidup dalam jumlah lebih besar daripada bayi laki-laki dikebanyakan Negara berkembang termasuk Indonesia.

\section{KESIMPULAN}

Berdasarkan hasil penelitian menunjukkan bahwa jumlah balita yang diberikan ASI sebesar 11,7\%, sedangkan jumlah balita yang mengalami stunting sebesar $35 \%$, dan ada hubungan yang signifikan antara pemberian ASI dengan kejadian stunting pada balita usia 24 bulan dengan nilai $\mathrm{P}=0,013$.

\section{SARAN}

Disarankan kepada orangtua yang mempunyai balita harus memberikan ASI secara efisien selama 6 bulan dan secara rutin mengikuti kegiatan posyandu setiap bulan guna mengetahui perkembangan dan pertumbuhan balita.

\section{DAFTAR PUSTAKA}

Black RE, Victoria CG, Walker SP, Bhutta ZA, Christian $P$, de Onis M et al. (2013). Maternal and Child Undernutrition and overweight in low-income and middle-income countries.

Mugianti. (2018). Faktor penyebab anak Stunting usia 25-60 bulan di Kecamatan Sukorejo Kota Blitar. Kebidanan, Poltekes Kemenkes Malang.

1 UNICEF. (2013). Ringkasan Kajian Gizi. Jakarta: Pusat Promosi Kesehatan. Kemenkes RI
1 Mugianti. (2018). Faktor penyebab anak Stunting usia 25-60 bulan di Kecamatan Sukorejo Kota Blitar. Kebidanan, Poltekes Kemenkes Malang.

1 Dinas Kesehatan Kabupaten Sintang. (2018). Profil Dinas Kesehatan Kabupaten Sintang 2018. Bidang KIA Dinas Kesehatan Kabupaten Sintang

Proverawati, A. dan Rahmawatiti, E. (2010). ASI dan Menyusui. Nuha Medika. Yogyakarta.

Taufiqurrahman. (2009). Defisiensi Vitamin Á dan Zinc Sebagai Faktor Risiko Terjadinya Stunting Pada Balita di Provinsi Nusa Tenggara Barat. Tesis. Fakultas Kedokteran. UGM. Yogyakarta

Kemenkes RI. (2019). Profil Kesehatan Indonesia Ditjen P2P. Jakarta: Sekretariat Jenderal Kementerian Kesehatan

Oktavia, R. (2011). Hubungan Pengetahuan Sikap dan Perilaku Ibu dalam Pemberian ASI Eksklusif Dengan Status Gizi Baduta di Puskesmas Biaro Kecamatan Ampek Angkek Kabupaten Agam Tahun 2011 (Skripsi). Depok: FK UI.3

Khasanah DP, Hadi H, Paramashanti BA. (2016). Waktu Pemberian Makanan Pendamping ASI (MPASI) berhubungan dengan kejadian stunting anak usia 6-23 bulan di Kecamatan Sedayu. Jurnal Gizi dan Dietetik Indonesia (Indonesian Journal of Nutrition and Dietetics). 4 (2):105-111

Notoatmodjo, S. (2010). Metodologi Penelitian Kesehatan. Jakarta: PT Rineka Cipta

Senbanjo, I., et al. (2011). Prevalence of and Risk factors for Stunting among School Children and Adolescents in Abeokuta, Southwest Nigeria. 
Journal of Health Population and Nutrition. 29(4):364-370

${ }^{1}$ Setiawan, E., Machmud, R., \& Masrul, M. (2018). Faktor-Faktor yang Berhubungan dengan Kejadian Stunting pada Anak Usia 24-59 Bulan di Wilayah Kerja Puskesmas Andalas Kecamatan Padang Timur Kota Padang Tahun 2018. Jurnal Kesehatan Andalas, 7(2), 275284.

Trihono, dkk. (2015). Pendek (Stunting) di Indonesia, Masalah dan Solusinya. Jakarta: Badan Penelitian dan Pengembangan Kesehatan. ${ }^{1}$ Khaldun, Syamsu. (2008). Z-Skor Status Gizi Balita di Provinsi Sulawesi Selatan. 112-125.

${ }^{1}$ Wahdah, S., Juffrie, M. \& Huriyati, E. (2015). Faktor risiko kejadian stunting pada anak umur 6- 36 bulan di wilayah pedalaman Kecamatan Silat Hulu, Kapuas Hulu, Kalimantan Barat. Jurnal Gizi dan Dietetik Indonesia, Volume 3, pp. 119-130

1Medhin, Gima et al. (2010). Prevalence and Predictors of Undernutrition Among Infants Age Six and Twelve Months In Butajira, Ethiopia: The P-MaMiE Birth Cohort. Mdhin et al. BMC Public Health, 10:27. Dapat diakses www.biomedcentral.com.

${ }^{1}$ Lesiapeto, et al. (2010). Risk Factors of Poor Anthropometric Status In Children Under Five Years of Age Living In Rural Districts of The Eastern Cape And Kwazulu-Natal Province, South Africa. S Afr J Clin Nutr, 23(4): 202-207. Dapat diakses di www.sajcn.co.za

Ramli, et al. (2009). Prevalence and Risk Factor for Stunting and Severe Stunting Among Under Fives in North Maluku Province of Indeonesia. BMC Pediatrics.
Press, Inc. Florida. Page. 147198.

Nugroho, P. S., Tianingrum, N. A., Sunarti, S., Rachman, A., Fahrurodzi, D. S., \& Amiruddin, R. (2020). Predictor risk of diabetes mellitus in Indonesia, based on national health survey. Malaysian Journal of Medicine and Health Sciences, 16(1), 126-130.

Nugroho, P. S., Wijayanti, A. C., \& Sunarti, S. (2020). Obesity and Its Risk Factors Among Adolescent in Indonesia. Malaysian Journal of Medicine and Health Sciences, 16(May), 173-179.

Praditasari, J. A., \& Sumarmik, S. (2018). Asupan Lemak, Aktivitas Fisik Dan Kegemukan Pada Remaja Putri Di Smp Bina Insani Surabaya. Media Gizi Indonesia, 13(2), 117. https://doi.org/10.20473/mgi.v 13i2.117-122

Salam, A. (2010). Faktor risiko kejadian obesitas pada remaja. Jurnal MKMI, 6(3), 185-190.

Sidiartha, I. G. L., \& Juliantini, N. P. L. (2015). Hubungan Riwayat Obesitas Pada Orangtua Dengan Kejadian Obesitas Pada Anak Sekolah Dasar. E-Jurnal Medika Udayana, 3(12), 1-13.

https://ojs.unud.ac.id/index.php /eum/article/view/11950

Teixeira, E. (2011). The effectiveness of communitybased programs for obesity prevention and control. Patient Intelligence, 63.

https://doi.org/10.2147/pi.s123 14

Yulnefia. (2015). Kejadian Overweight Pada Remaja Di Analis Kesehatan Abdurrab Insidence. Collaborative Medical Journal, 000, 39-48. 